\title{
Persepsi Petani Terhadap Program Upsus Pajale di Kecamatan Natar Kabupaten Lampung Selatan
}

\section{Farmers Perception of the Upsus Pajale Program in Natar Sub-District, South Lampung District}

\author{
Oleh : \\ Bella Chyntia $^{1 *}$, Dame Trully Gultom ${ }^{2}$, Rio Tedi Prayitno ${ }^{2}$ \\ ${ }^{1}$ Jurusan Agribisnis, Fakultas Pertanian, Universitas Lampung \\ ${ }^{2}$ Program Studi Penyuluhan Pertanian, Fakultas Pertanian, Universitas Lampung \\ Jl. Sumantri Brojonegoro 1, Bandar Lampung, 35145, Lampung, Indonesia \\ *Email : bellaachyntia21@gmail.com
}

Received March 03, 2020; Revised June 22, 2020; Accepted June 25, 2020

\begin{abstract}
ABSTRAK
Penelitian ini bertujuan untuk mengetahui tingkat keberhasilan, persepsi petani dan faktor-faktor yang berhubungan dengan persepsi petani terhadap Program Upsus Pajale. Penelitian ini dilakukan di Kecamatan Natar Kabupaten Lampung Selatan. Sampel dalam penelitian ini berjumlah 51 orang petani responden yang dipilih secara acak. Metode analisis data menggunakan analisis deskriptif kuantitatif, tabulasi, dan Korelasi Rank Spearman. Hasil penelitian menunjukkan bahwa Program Upsus Pajale belum berhasil. Sebagian besar petani belum menerapkan tahapan-tahapan dari Program Upsus Pajale, petani jarang mengikuti rapat terkait pelaksanaan program, serta produktivitas padi mengalami penurunan dari tahun 2018 sebesar 2,42 ton/ha/musim tanam dan produktivitas jagung mengalami penurunan dari tahun 2018 sebesar 2,30 ton/ha/musim tanam. Persepsi petani tentang Program Upsus Pajale sangat baik. Faktor-faktor yang berhubungan dengan persepsi petani dalam Program Upsus Pajale adalah pengalaman berusahatani, motivasi, dan tingkat pengetahuan.
\end{abstract}

Kata kunci: penyuluhan, persepsi, produktivitas, Program Upsus Pajale

\begin{abstract}
The purposes of this study were to know the level of success, perceptions and factors that related to farmers' perceptions of the Upsus Pajale Program. This research was conducted in Natar SubDistrict, South Lampung District. The samples in this study amounted to 51 respondent farmers who were randomly selected. The method of data analysis were uses quantitative descriptive analysis, tabulation, and Spearman Rank Correlation. The results showed that the Upsus Pajale Program has not been successful. Most farmers had not implemented the Upsus Pajale Program, farmers rarely participate in related programs, and rice productivity has decreased from 2018 by 2,42 ton/ha and corn productivity had decreased from 2018 by 2,30 ton/ha, the farmers' perception of the Upsus Pajale Program were very good about the Upsus Pajale Program. Farmers' perceptions about the Upsus Pajale Program were very good. Factors related to farmers 'perceptions in Upsus Pajale Program were farming experience, motivation, and level of knowledge, while factors not related to farmers' perceptions in Upsus Pajale Program were formal education, non-formal education, and age of farmers.
\end{abstract}

Keywords: extension, perception, productivity Upsus Pajale Program. 


\section{PENDAHULUAN}

Pangan merupakan kebutuhan dasar manusia yang paling utama, oleh karena itu pemenuhan ketersediaan pangan harus memiliki jumlah cukup, mutu baik, dan harga terjangkau. Hal ini ditujukan agar seluruh masyarakat dapat memperoleh pangan dengan mudah agar kebutuhan tubuhnya dapat terpenuhi dengan baik. Mengingat pentingnya memenuhi kecukupan pangan, setiap negara mendahulukan pembangunan ketahanan pangannya sebagai pondasi bagi pembangunan sektor-sektor lainnya (Dewan Ketahanan Pangan 2012).

Menurut Undang-Undang Pangan Nomor 18 Tahun 2012 tentang ketahanan pangan, ketahanan pangan adalah kondisi terpenuhinya pangan bagi negara sampai perseorangan, yang tercermin dari tersedianya pangan yang cukup, baik jumlah maupun mutunya, aman, beragam, bergizi, merata dan terjangkau serta tidak bertentangan. Salah satu upaya untuk mewujudkan ketahanan pangan Kementerian Pertanian Republik Indonesia, menggulirkan program untuk meningkatkan swasembada pangan. Program peningkatan swasembada pangan yaitu Program Upaya Khusus Padi, Jagung, dan Kedelai (Upsus Pajale). Upsus Pajale dilakukan pemerintah untuk meningkatkan produktivitas tanaman pangan di daerah-daerah sentra produksi pangan di Indonesia, salah satunya di Provinsi Lampung

Kabupaten Lampung Selatan merupakan salah satu kabupaten yang mengikuti Program Upsus Pajale di Provinsi Lampung dengan luas panen, produksi dan produktivitas tanaman pangan padi, jagung, dan kedelai yang cukup tinggi. Produksi padi di Kecamatan Natar menduduki urutan tertinggi ketiga setelah Kecamatan Palas dan Kecamatan Candipuro yang memiliki luas panen tanaman padi sebesar 9.106 ha dan produksi sebesar 49.966 ton dengan produktivitas 5,49 ton/ha. Produksi jagung di Kecamatan Natar menduduki urutan tertinggi keempat dari 17 kecamatan setelah
Kecamatan Penengahan, Kecamatan Ketapang dan Kecamatan Kalianda yang memiliki luas panen tanaman jagung sebesar 12.252 ha dan produksi sebesar 65.756 ton dengan produktivitas 5,37 ton/ha (Badan Pusat Statisik Kabupaten Lampung Selatan 2017).

Kecamatan Natar memiliki luas panen, produksi padi dan jagung yang cukup tinggi. Produksi yang tinggi tidak terlepas dari komunikasi yang baik antara penyuluh lapangan dan petani (Wahyuni, 2019). Upaya peningkatan produksi usahatani padi jagung dan kedelai tentunya tidak terlepas dari persepsi petani terhadap Program Upsus Pajale. Hal ini karena persepsi sangat erat hubungannya dengan sikap dan respon seseorang terhadp objek tertentu dalam hal ini adalah Program Upsus Pajale dalam meningkatkan produksi usahatni petani (Haryani, 2014; Hasanuddin et al. 2019).

Persepsi petani terhadap Program Upsus Pajale sangat penting, karena petani adalah pelaku utama dalam kegiatan Program Upsus Pajale. Persepsi setiap individu terhadap suatu objek berbeda-beda begitu pula terhadap suatu program. Proses persepsi individu dituntut untuk memberikan penilaian terhadap suatu obyek yang dapat bersifat positif/negatif, senang atau tidak senang dan sebagainya, dengan adanya persepsi maka akan terbentuk sikap yaitu suatu kecenderungan yang stabil untuk berlaku atau bertindak secara tertentu didalam situasi yang tertentu pula (Yanfika et al. 2019; Nurmayasari et al. 2020). Persepsi petani dapat dilihat dari keberhasilan Program Upsus Pajale, jika petani memiliki persepsi yang baik, maka program diharapkan berjalan dengan baik dan dapat dilanjutkan pada masa-masa selanjutnya (Rangga et al. 2020; Viantimala et al. 2020). Sebaliknya, jika persepsi petani terhadap program tidak baik, maka program tersebut tidak akan berlangsung dengan baik, mengalami gangguan bahkan tidak dapat berjalan dan akan sulit untuk melanjutkan program tersebut (Sukmayanto et al. 2019; Cindoswari dan Abidin, 2019). . 
Berdasarkan uraian tersebut, maka tujuan dari penelitian ini adalah untuk mengetahui tingkat keberhasilan pelaksanaan Program Upsus, mengetahui persepsi petani terhadap Program Upsus Pajale, dan menganalisis faktor-faktor yang berhubungan dengan persepsi petani terhadap Program Upsus Pajale di Kecamatan Natar Kabupaten Lampung Selatan.

\section{METODE PENELITIAN}

Metode yang digunakan dalam penelitian ini adalah metode survei. Penelitian ini dilakukan di Kecamatan Natar Kabupaten Lampung Selatan. Pemilihan lokasi dilakukan secara sengaja (purposive) dengan pertimbangan bahwa Kecamatan Natar merupakan salah satu kecamatan yang ada di Kabupaten Lampung Selatan dengan produksi padi tertinggi ketiga dan produksi jagung menempati posisi tertinggi ketiga dari 17 kecamatan yang ada di Kabupaten Lampung Selatan. Penelitian ini dilakukan pada bulan Januari-Februari 2019.

Pada penelitian ini proses pengumpulan data dilakukan dengan menggunakan kuisioner. Data yang dikumpulkan berupa data primer dan data sekunder. Data primer berupa data yang diambil langsung dari responden dengan instrumen kuisioner yang telah dibuat sebelum melalui wawancara. Data sekunder diperoleh dari studi literatur, laporanlaporan, dan pustaka lainnya yang berhubungan dengan penelitian ini serta lembaga instansi yang terkait dalam penelitian ini seperti BPPP.

Responden penelitian adalah petani peserta Program Upsus Pajale di Kecamatan Natar Kabupaten Lampung Selatan. Pengambilan sampel diambil dari enam desa yaitu Desa Sidosari, Desa Pancasila, Desa Hajimena, Desa Negara Ratu, Desa Tanjung Sari, dan Desa Pemanggilan. Jumlah petani padi dan jagung di enam desa tersebut berjumlah 148 orang. Metode pengambilan petani sampel dilakukan dengan metode simple random sampling (acak sederhana) yaitu metode yang digunakan untuk memilih sampel dari populasi dengan cara sedemikian rupa sehingga setiap anggota populasi mempunyai peluang yang sama besar untuk diambil sebagai sampel (Sugiarto dkk 2003) dengan rumus sebagai berikut:

$\mathrm{n}=\frac{\mathrm{NZ}^{2} \mathrm{~S}^{2}}{\mathrm{Nd}^{2}+\mathrm{Z}^{2} \mathrm{~S}^{2}}$

Keterangan:

$\mathrm{N}=$ Jumlah sampel

$\mathrm{N}=$ Jumlah populasi petani (148 orang)

$\mathrm{Z}=$ Tingkat kepercayaan $(95 \%=1,96)$

$S^{2}=$ Variasi sampel $(5 \%=0,05)$

$\mathrm{d}=$ Derajat penyimpangan $(5 \%=0,05)$

Berdasarkan perhitungan dengan rumus diatas, diperoleh jumlah sampel untuk petani yang mengikuti Program Upsus Pajale di Kecamatan Natar adalah 51 responden. Adapun perhitungan tersebut sebagai berikut:

$\mathrm{n}$

$$
\begin{aligned}
& =\frac{(148)(1,96)^{2}(0,05)}{148(0,05)^{2}+(1,96)^{2}(0,05)} . \\
& \mathrm{n}=50,77 \approx 51
\end{aligned}
$$

Metode analisis data pada penelitian ini yaitu metode deskriptif kuantitatif. Metode pengolahan data dilakukan dengan menggunakan metode tabulasi dan statistika non parametrik Korelasi Rank Spearman. Pengujian hipotesis menggunakan statistik non parametrik, uji Koefisien Korelasi Rank Spearman (Siegel,1997) dengan rumus sebagai berikut

$r S=1-\frac{6 \sum_{\mathrm{i}-1}^{\mathrm{n}} \mathrm{di}^{2}}{\mathrm{n}^{3}}$

Keterangan :

$r_{\mathrm{s}}=$ Penduga koefisien korelasi

$\mathrm{di}=$ Perbedaan setiap pasangan rank

$\mathrm{n}=$ Jumlah responden 
Kaidah pengambilan keputusan dalam penelitian ini ditentukan dengan bantuan aplikasi SPSS Versi 24. Kaidah pengambilan keputusan adalah sebagai berikut:

1. Jika nilai signifikansi $\leq(\alpha)=0,05$ atau $(\alpha)=0,01$ maka terima $\mathrm{H}_{1}$, berarti terdapat hubungan antara kedua variabel yang diuji.

2. Jika nilai signifikansi $>(\alpha)=0,05$ atau $(\alpha)=0,01$ maka tolak $\mathrm{H}_{1}$, berarti tidak terdapat hubungan antara kedua variabel yang diuji.

\section{HASIL DAN PEMBAHASAN}

\section{Gambaran Umum Kecamatan Natar}

Kecamatan Natar merupakan kecamatan terluas di Lampung Selatan yaitu sekitar 12 persen dari total luas Lampung Selatan. Kecamatan Natar terdiri dari 26 desa. Ketinggian desa-desa di Kecamatan Natar rata-rata di bawah $100 \mathrm{~m}$ dari permukaan laut dengan topografi berupa dataran maka banyak dimanfaatkan untuk lahan pertanian, sehingga sebagian besar masyarakatnya bekerja sebagai petani. Komoditas pertanian tanaman pangan yang dibudidayakan di Kecamatan Natar antara lain adalah tanaman padi, jagung, ubi kayu, ubi jalar, kacang tanah, kedelai dan kacang hijau.

\section{Keberhasilan Upsus Pajale}

Keberhasilan Program Upsus Pajale adalah tercapainya tujuan yang diinginkan oleh semua orang yang mengikuti dan berperan dalam kegiatan Upsus Pajale. Keberhasilan Program Upsus Pajale dapat diukur melalui peningkatan Indeks Pertanaman (IP) minimal sebesar 0,5, peningkatan produktivitas padi minimal sebesar 0,3 ton/ha GKP, dan meningkatnya produktivitas jagung sebesar 1 ton/ha pada areal existing. Sebaran petani responden berdasarkan indeks pertanaman dapat dilihat pada Tabel 1.
Tabel 1 menunjukkan bahwa Indeks Pertanaman di Kecamatan Natar Kabupaten Lampung Selatan memperoleh rata-rata skor sebesar 2,00 yang tergolong pada kategori sedang. Indeks Pertanaman di Kecamatan Natar Kabupaten Lampung Selatan dapat dikatakan cukup baik dimana pada Peraturan Menteri Pertanian Nomor 3 Tahun 2015 tentang Pedoman Upaya Khusus (Upsus) Pajalemengatur bahwa indeks pertanaman yang ditargetkan yaitu meningkat 0,5 dari 2 kali tanam dalam setahun. Adapun kendala yang dihadapi apabila meningkatkan indeks pertanaman $>2$, yaitu akan menimbulkan serangan hama karena penanaman yang tidak serentak sebab masih banyak petani yang hanya menanam 2 kali musim tanam karena kekurangan modal dan keterbatasan sumberdaya air.

Tabel 1.

Sebaran responden berdasarkan indeks pertanaman petani dalam Program Upsus Pajale di Kecamatan Natar

\begin{tabular}{ccrr}
\hline $\begin{array}{c}\text { Indek } \\
\begin{array}{c}\text { Pertanaman } \\
\text { (Skor) }\end{array}\end{array}$ & Klasifikasi & $\begin{array}{c}\text { Jumlah } \\
\text { Responden }\end{array}$ & $\begin{array}{c}\text { Persentase } \\
(\%)\end{array}$ \\
\hline 1 & Rendah & 21 & 41,18 \\
2 & Sedang & 26 & 50,98 \\
3 & Tinggi & 4 & 7,84 \\
\hline Jumlah & & $\mathbf{5 1}$ & $\mathbf{1 0 0 , 0 0}$ \\
\hline Rata-rata : 2 (Sedang) & & \\
\hline
\end{tabular}

Produktivitas adalah produksi yang dihasilkan dan dibagi luas lahan dalam satu musim tanam. Secara rinci sebaran produktivitas tanaman padi dan jagung responden pada Program Upsus Pajale di Kecamatan Natar Kabupaten Lampung Selatan beserta penjelasannya dapat diljelaskan pada Tabel 2. Tabel 2 menunjukkan bahwa produktivitas tanaman padi berdasarkan indeks pertanaman dalam setahun dalam Program Upsus Pajale tergolong pada klasifikasi rendah yaitu sebesar (70,00\%). Berdasarkan hasil penelitian produktivitas padi di Kecamatan Natar tergolong rendah dikarenakan, adanya serangan hama wereng dan kurang nya pasokan air ketika petani melakukan penanaman. Produktivitas padi di 
Kecamatan Natar sebesar 4,47 ton/ha mengalami penurunan sebesar 2,42 ton/ha dari sebelum dilaksanakannya Program Upsus Pajale yaitu sebesar 6,89 ton/ha, dan produktivitas tanaman jagung sesudah Program Upsus Pajale berada pada klasifikasi sedang dengan nilai rata-rata produktivitas sebesar 10,29 ton/ha. Produktivitas jagung di Kecamatan Natar sebesar 10,29 ton/ha mengalami penurunan sebesar 2,30 Ton/ha dari sebelum dilaksanakannya Program Upsus Pajale yaitu sebesar 12,58 ton/ha.

Tabel 2.

Sebaran Produktivitas Padi dan Jagung pada Program Upsus Pajale di Kecamatan Natar

\begin{tabular}{cccc}
\hline $\begin{array}{c}\text { Produktivitas } \\
\text { Padi (ton/ha) }\end{array}$ & Klasifikasi & $\begin{array}{c}\text { Jumlah } \\
\text { Responden }\end{array}$ & $\begin{array}{c}\text { Persentase } \\
(\%)\end{array}$ \\
\hline $1,3-5,1$ & Rendah & 21 & 70,00 \\
$5,2-9,0$ & Sedang & 5 & 16,67 \\
$9,1-12,7$ & Tinggi & 4 & 13,33 \\
\hline Jumlah & & $\mathbf{3 0}$ & $\mathbf{1 0 0 , 0 0}$ \\
\hline \multicolumn{2}{l}{ Rata-rata =4,47 (Rendah) } & & \\
\hline $\begin{array}{l}\text { Produktivitas } \\
\text { Jagung }\end{array}$ & Klasifikasi & Jumlah & Persentase \\
(ton/ha) & & Responden & $(\%)$ \\
\hline $1,7-7,3$ & Rendah & 8 & 38,10 \\
$7,4-13,0$ & Sedang & 4 & 19,05 \\
$13,1-18,5$ & Tinggi & 9 & 42,86 \\
\hline Jumlah & & $\mathbf{2 1}$ & $\mathbf{1 0 0 , 0 0}$ \\
\hline Rata-rata $=\mathbf{1 0 , 2 9}$ (Sedang) & & \\
\hline
\end{tabular}

\section{Persepsi Petani dalam Program Upsus Pajale}

Persepsi merupakan suatu aspek psikologis yang penting bagi manusia dalam merespon kehadiran berbagai aspek dan gejala di sekitarnya. Tabel 3 menunjukkan persepsi petani tentang Program Upsus Pajale berada pada klasifikasi tinggi. Sebanyak 21 orang responden $(41,18 \%)$ memiliki persepsi yang baik tentang Program Upsus Pajale. Petani sangat memahami tentang Program Upsus Pajale, dikarenakan penyuluh maupun dari ketua kelompok tani sangat sering memberi informasi tentang Program Upsus Pajale. Petani tahu mengenai tujuan, ruang lingkup, dan sistem pendanaan pada program upsus pajale, dan Petani cukup memahami tentang Program Upsus Pajale, dikarenakan penyuluh pertanian lapangan maupun dari ketua kelompok tani cukup sering memberi informasi tentang Program Upsus Pajale.

Tabel 3.

Sebaran petani responden berdasarkan persepsi petani tentang Program Upsus Pajale di

Kecamatan Natar Kabupaten Lampung Selatan

\begin{tabular}{lccc}
\hline Selang Interval & $\begin{array}{c}\text { Klasifi- } \\
\text { kasi }\end{array}$ & $\begin{array}{c}\text { Responden } \\
\text { (Orang) }\end{array}$ & $(\%)$ \\
\hline $12,547-15,768$ & Rendah & 12 & 23,53 \\
$15,769-18,990$ & Sedang & 18 & 35,29 \\
$18,991-22,212$ & Tinggi & 21 & 41,18 \\
\hline Total & & $\mathbf{5 1}$ & $\mathbf{1 0 0 , 0 0}$ \\
\hline $\begin{array}{l}\text { Rata-rata } \\
\text { (Sedang) }\end{array}$ & $\mathbf{1 8 , 0 7}$ & & \\
\hline
\end{tabular}

Faktor-faktor yang Berhubungan dengan Persepsi Petani dalam Program Upsus Pajale

Faktor-faktor yang berhubungan dengan persepsi petani dalam Program Upsus Pajale di Kecamatan Natar Kabupaten Lampung Selatan dapat dilihat pada Tabel 4.

Tabel 4.

Sebaran petani responden berdasarkan faktorfaktor yang berhubungan dengan persepsi petani dalam Program Upsus Pajale

\begin{tabular}{|c|c|c|c|c|}
\hline Variabel & $\begin{array}{l}\text { Selang } \\
\text { Interval }\end{array}$ & Klasifikasi & $\begin{array}{l}\text { Responden } \\
\text { (Orang) }\end{array}$ & $(\%)$ \\
\hline \multirow{3}{*}{$\begin{array}{c}\text { Tingkat } \\
\text { Pengalaman } \\
\text { Berusahatani } \\
\text { (Tahun) }\end{array}$} & $9-16$ & Rendah & 8 & 15,69 \\
\hline & $17-23$ & Sedang & 29 & 56,86 \\
\hline & $24-30$ & Tinggi & 14 & 27,45 \\
\hline \multirow{2}{*}{\multicolumn{2}{|c|}{$\begin{array}{l}\text { Total } \\
\text { Rata-rata }=21,14 \text { (Sedang) }\end{array}$}} & & 51 & 100 \\
\hline & & & & \\
\hline $\begin{array}{l}\text { Motivasi } \\
\text { (Skor) }\end{array}$ & $\begin{array}{l}24,91-31,34 \\
31,34-37,77 \\
37,77-44,20 \\
\end{array}$ & $\begin{array}{l}\text { Rendah } \\
\text { Sedang } \\
\text { Tinggi } \\
\end{array}$ & $\begin{array}{l}12 \\
29 \\
10 \\
\end{array}$ & $\begin{array}{l}23,53 \\
56,86 \\
19,61 \\
\end{array}$ \\
\hline \multicolumn{2}{|l|}{ Total } & & 51 & 100 \\
\hline \multicolumn{5}{|c|}{ Rata-rata =33.62 $($ Sedang $)$} \\
\hline \multirow{2}{*}{$\begin{array}{c}\text { Tingkat } \\
\text { Pengetahuan } \\
\text { Petani } \\
\text { (Skor) } \\
\end{array}$} & $\begin{array}{l}19,53-23,98 \\
23,98-28,42\end{array}$ & $\begin{array}{l}\text { Rendah } \\
\text { Sedang }\end{array}$ & $\begin{array}{l}10 \\
28\end{array}$ & $\begin{array}{l}19,61 \\
54,90\end{array}$ \\
\hline & $28,42-32,87$ & Tinggi & 13 & 25,49 \\
\hline \multicolumn{2}{|l|}{ Total } & & 51 & 100 \\
\hline \multicolumn{5}{|c|}{ Rata-rata = 26,51 (Sedang) } \\
\hline \multirow{3}{*}{$\begin{array}{c}\text { Tingkat } \\
\text { Pendidikan } \\
\text { Formal } \\
\end{array}$} & SMA & & 23 & 45,1 \\
\hline & SMP & & 20 & 39,21 \\
\hline & $\mathrm{SD}$ & & 8 & 15,69 \\
\hline \multicolumn{2}{|c|}{ Total } & & 51 & 100 \\
\hline \multicolumn{5}{|c|}{ Rata-rata = SMA } \\
\hline \multirow{3}{*}{$\begin{array}{c}\text { Tingkat } \\
\text { Pendidikan } \\
\text { Nonformal } \\
\text { (Frekuensi) }\end{array}$} & $1-5$ & Rendah & 4 & 7,84 \\
\hline & $6-10$ & Sedang & 23 & 45,1 \\
\hline & $>10$ & Tinggi & 24 & 47,06 \\
\hline \multicolumn{2}{|l|}{ Total } & & 51 & 100 \\
\hline \multicolumn{5}{|c|}{ Rata-rata $=2,39$ (Sedang $)$} \\
\hline \multirow{3}{*}{$\begin{array}{l}\text { Usia Petani } \\
\text { (Tahun) }\end{array}$} & $36-45$ & & 16 & 31,37 \\
\hline & $46-55$ & & 27 & 52,94 \\
\hline & $56-65$ & & 8 & 15,69 \\
\hline Total & & & 51 & 100 \\
\hline
\end{tabular}


Rata-rata $=48$ (Sedang)

\section{Tingkat Pengalaman Berusahatani (X1)}

Pengalaman usahatani petani merupakan salah satu faktor yang berhubungan dengan persepsi petani dalam Program Upsus Pajale kerena suatu program akan terlaksana dengan baik apabila anggotanya memiliki pengalaman yang cukup baik dalam program tersebut untuk mencapai tujuan yang telah ditetapkan. Tingkat pengalaman berusahatani petani ditentukan berdasarkan berapa lama pengalaman petani berusahatani. Rata-rata tingkat pengalaman usahatani petani berada pada klasifikasi sedang dengan rata-rata pengalaman usahatani selama 21 tahun. Responden menyatakan bahwa sosialisasi yang dilakukan oleh penyuluh terkait Program Upsus Pajale dapat menambah wawasan serta pengetahuan yang cukup untuk mengelola usahataninya.

\section{Motivasi (X2)}

Motivasi adalah dorongan yang bersumber dari diri seorang petani yang menggerakkan semangatnya untuk melaksanakan Program Upsus Pajale. Tabel 4 menunjukkan tingkat motivasi petani terhadap Program Upsus Pajale berada pada klasifikasi sedang $(56,86 \%)$ dengan nilai rata-rata 33,62. Menurut responden, petani cukup termotivasi dengan adanya sosialisasi yang dilakukan oleh penyuluh terkait Program Upsus Pajale untuk meningkatkan produksi usahatani mereka, petani berpendapat bahwa dengan meningkatnya produksi usahataninya maka pendapatan akan meningkat.

\section{Tingkat Pengetahuan Petani (X3)}

Pengetahuan petani mengenai Program Upsus Pajale terhadap tujuan, ruang lingkup, pendanaan, dan struktur organisasi pelaksanaan Program Upsus Pajale berkaitan dengan persepsi petani. Tabel 4 menunjukkan tingkat pengetahuan tentang
Program Upsus Pajale berada pada klasifikasi sedang $(54,90 \%)$ dengan nilai rata-rata 26,51. menyatakan bahwa Petani cukup mengetahui tentang Program Upsus Pajale, dikarenakan dari penyuluh pertanian lapangan maupun dari ketua kelompok tani cukup sering memberi informasi tentang Program Upsus Pajale. Petani cukup tahu mengenai tujuan, ruang lingkup, dan sistem pendanaan pada Program Upsus Pajale.

\section{Pendidikan Formal (X4)}

Tingkat pendidikan merupakan salah satu faktor yang dapat menentukan keberhasilan petani dalam melakukan usahatani. Semakin tinggi pendidikan petani, semakin besar potensi keberhasilan usahatani petani. Tabel 4 menunjukkan tingkat pendidikan formal petani berada pada klasifikasi tinggi. Sebanyak 23 orang responden $(45,10 \%)$ merupakan lulusan SMA (sekolah menengah atas), Tingkat pendidikan dapat membantu petani dalam mengambil keputusan pada usahataninya. Semakin tinggi tingkat pendidikan petani maka semakin mudah petani dalam menerima inovasi-inovasi baru terutama dalam bidang pertanian dibandingkan petani yang berpendidikan rendah.

\section{Pendidikan Nonformal (X5)}

Pendidikan nonformal petani yaitu proses belajar yang dilaksanakan di lahan petani, di lingkungan keluarga/masyarakat setempat. Lahan usahatani digunakan selama proses belajar. Tabel 4 menunjukkan tingkat pendidikan nonformal, sebanyak 24 orang responden $(47,06 \%)$ berada pada klasifikasi tinggi. Tingkat pendidikan nonformal dapat menambah wawasan dan pengalaman berusahatani serta memberi pengetahuan petani, sehingga petani menjadi tahu, mau dan mampu dalam menjalankan program baru dalam usahatani seperti Program Upsus Pajale. Pendidikan nonformal petani diperoleh dari sekolah lapang yang diselenggarakan oleh penyuluh pertanian lapangan, pertemuan-pertemuan 
dengan instansi seperti dinas pertanian, ketahanan pangan, dan lainnya.

Usia Petani (X6)

Usia petani merupakan salah satu penentu dalam menjalankan suatu usahatani. Secara tidak langsung usia dapat berpengaruh terhadap fisik seseorang yang dibutuhkan untuk menjalankan usahataninya. Tabel 4 menunjukkan bahwa mayoritas usia responden pada penelitian ini berkisar antara 46-55 tahun dengan persentase sebesar 52,94\%, rata-rata usia responden pada penelitian ini yaitu 48 tahun. Seseorang dengan usia yang produktif mampu menjalankan suatu kegiatan dengan baik sedangkan seseorang dengan usia yang tidak produktif menjadi kurang maksimal dalam menjalankan kegiatan dikarenakan keterbatasan fisik yang mudah lelah. Menurut Mantra (2003), seseorang masuk kedalam usia produktif apabila usianya berkisar antara 15-64 tahun, sehingga rata-rata responden pada penelitian ini masih tergolong pada usia produktif.

\section{Hasil Pengujian Hipotesis}

Hubungan antara variabel X (faktorfaktor yang berhubungan dengan persepsi petani) dengan variabel $\mathrm{Y}$ (persepsi petani) serta variabel $\mathrm{Z}$ (keberhasilan Program Upsus Pajale) dianalisis dengan menggunakan uji Korelasi Rank Spearman dengan SPSS 16.

Hubungan antara Persepsi Petani dengan Keberhasilan Program Upsus Pajale

Berdasarkan hasil uji statistik yang telah dilakukan menunjukkan bahwa hubungan antara persepsi petani (Y) dengan keberhasilan Program Upsus Pajale (Z) diperoleh nilai koefisien Kolerasi Rank Spearman (rs) sebesar 0,315. Hal ini menunjukkan bahwa hubungan antara persepsi petani (Y) dengan keberhasilan Program Upsus Pajale (Z) ditentukan sebesar 0,315. Nilai signifikasi sebesar 0,024 lebih kecil dari $\alpha(0,05)$, maka dapat diambil keputusan untuk terima $\mathrm{H} 1$, artinya persepsi petani memiliki hubungan nyata dengan keberhasilan Program Upsus Pajale di Kecamatan Natar Kabupaten Lampung Selatan. Semakin baik persepsi petani tentang program upsus pajale maka semakin baik pula hasil dari Program Upsus Pajale.

\section{Hubungan antara Tingkat Pengalaman Berusahatani Petani dengan Persepsi Petani dalam Program Upsus Pajale}

Berdasarkan hasil uji statistik yang telah dilakukan menunjukkan bahwa hubungan antara tingkat pengalaman berusahatani petani (X1) dengan persepsi petani dalam Program Upsus Pajale (Y) diperoleh nilai koefisien kolerasi Rank Spearman $\left(\mathrm{r}_{\mathrm{s}}\right)$ sebesar 0,919 .

Hal ini menunjukkan bahwa hubungan antara pengalaman berusahatani petani (X1) dengan persepsi petani dalam Program Upsus Pajale (Y) ditentukan sebesar 0,919. Nilai signifikasi sebesar 0,000 lebih kecil dari $\alpha(0,05)$, maka dapat diambil keputusan untuk terima $\mathrm{H}_{1}$, artinya pengalaman berusahatani petani berhubungan nyata dengan persepsi petani dalam Program Upsus Pajale di Kecamatan Natar Kabupaten Lampung Selatan. Semakin lama pengalaman berusahatani petani maka semakin baik persepsi petani terhadap program Upsus Pajale. Hasil penelitian ini sejalan dengan penelitian Robiyan (2014) yang berjudul Persepsi petani terhadap Program SL-PHT dalam meningkatkan produktivitas dan pendapatan usahatani dan faktor yang berhubungan nyata terhadap persepsi petani kakao yaitu tingkat pengalaman berusahatani, tingkat pengetahuan usahatani dan tingkat interaksi sosial.

Hubungan antara Motivasi Petani dengan Persepsi Petani dalam Program Upsus Pajale

Berdasarkan hasil uji statistik yang telah dilakukan menunjukkan bahwa hubungan antara tingkat motivasi petani 
(X2) dengan persepsi petani dalam Program Upsus Pajale (Y) diperoleh nilai koefisien Kolerasi Rank Spearman $\left(\mathrm{r}_{\mathrm{s}}\right)$ sebesar 0,296. Hal ini menunjukkan bahwa hubungan antara motivasi petani (X2) dengan persepsi petani dalam Program Upsus Pajale (Y) ditentukan sebesar 0,296. Nilai signifikasi sebesar 0,035 lebih kecil dari $\alpha(0,05)$, maka dapat diambil keputusan untuk terima $\mathrm{H}_{1}$, artinya pengalaman berusahatani petani berhubungan nyata dengan persepsi petani dalam Program Upsus Pajale. Semakin tinggi motivasi petani maka semakin baik persepsi petani terhadap Program Upsus Pajale.

Hubungan antara Tingkat Pengetahuan dengan Persepsi Petani Program Upsus Pajale

Berdasarkan hasil uji statistik yang telah dilakukan menunjukkan bahwa hubungan antara tingkat pengetahuan (X3) dengan persepsi petani dalam Program Upsus Pajale (Y) diperoleh nilai koefisien Kolerasi Rank Spearman $\left(\mathrm{r}_{\mathrm{s}}\right)$ sebesar 0,305. Hal ini menunjukkan bahwa hubungan antara tingkat pengetahuan anggota (X3) dengan persepsi petani dalam Program Upsus Pajale (Y) ditentukan sebesar 0,305. Nilai signifikasi sebesar 0,029 lebih kecil dari $\alpha(0,05)$, maka dapat diambil keputusan untuk terima $\mathrm{H}_{1}$, artinya tingkat pengetahuan memiliki hubungan nyata dengan persepsi petani dalam Program Upsus Pajale di Kecamatan Natar Kabupaten Lampung Selatan. Semakin tinggi tingkat pengetahuan petani maka semakin baik persepsi petani terhadap program Upsus Pajale. Hasil penelitian ini sejalan dengan penelitian Dewinta (2018) yang menyimpulkan bahwa tingkat pengetahuan berhubungan nyata dengan persepsi anggota $\mathrm{KPPH}$.

Hubungan antara Pendidikan Nonformal Petani dengan Persepsi Petani Program Upsus Pajale
Berdasarkan hasil uji statistik yang telah dilakukan menunjukkan bahwa hubungan antara tingkat pendidikan nonformal petani (X5) dengan persepsi petani dalam Program Upsus Pajale (Y) diperoleh nilai koefisien Kolerasi Rank Spearman $\left(\mathrm{r}_{\mathrm{s}}\right)$ sebesar 0,132. Hal ini menunjukkan bahwa hubungan antara tingkat pendidikan nonformal petani (X5) dengan persepsi petani dalam Program Upsus Pajale (Y) ditentukan sebesar 0,132. Nilai signifikasi sebesar 0,357 lebih besar dari $\alpha(0,05)$, maka dapat diambil keputusan untuk tolak $\mathrm{H}_{1}$, artinya tingkat pendidikan nonformal petani tidak memiliki hubungan nyata dengan persepsi petani dalam Program Upsus Pajale di Kecamatan Natar Kabupaten Lampung Selatan.

Hubungan antara Usia Petani dengan Persepsi Petani Program Upsus Pajale

Berdasarkan hasil uji statistik yang telah dilakukan menunjukkan bahwa hubungan antara usia petani (X6) dengan persepsi petani dalam Program Upsus Pajale (Y) diperoleh nilai koefisien Kolerasi Rank Spearman $\left(\mathrm{r}_{\mathrm{s}}\right)$ sebesar 0,191. Hal ini menunjukkan bahwa hubungan antara usia petani (X6) dengan persepsi petani dalam Program Upsus Pajale (Y) ditentukan sebesar 0,191. Nilai signifikasi sebesar 0,180 lebih kecil dari $\alpha(0,05)$, maka dapat diambil keputusan untuk tolak $\mathrm{H}_{1}$, artinya usia petani tidak memiliki hubungan nyata dengan persepsi petani dalam Program Upsus Pajale.

\section{Aplikasi Penerapan Teori Komunikasi} Terhadap Program Upsus Pajale

Penelitian ini membahas mengenai persepsi petani terhadap Program Upsus Pajale. Salah satu faktor yang mempengaruhi keberhasilan Program Upsus Pajale adalah komunikasi. Komunikasi antara penyuluh dengan petani dapat berkaitan dengan persepsi petani. Pada penelitian ini PPL di Kecamatan Natar merupakan pihak yang memiliki informasi 
mengenai Program Upsus Pajale yang memahami ruang lingkup dari program tersebut. Kemudian, PPL akan menyampaikan informasi tentang Program Upsus Pajale kepada petani melalui media atau sarana yang tersedia di Kecamatan Natar seperti : handphone, kelompok tani dan internet, sedangkan petani merupakan pihak yang menerima informasi tentang Program Upsus Pajale dari PPL. Effect dari penyampaian pesan/informasi tersebut dapat menimbulkan persamaan persepsi petani terhadap program, peningkatan ekonomi pada setiap petani yang mengikuti program serta keberhasilan Program Upsus Pajale.

\section{SIMPULAN}

Program Upsus Pajale di Kecamatan Natar Kabupaten Lampung Selatan belum berhasil. Sebagian besar petani di Kecamatan Natar Kabupaten Lampung Selatan belum menerapkan tahapan-tahapan dari Program Upsus Pajale, petani jarang mengikuti rapat terkait pelaksanaan program, serta produktivitas padi mengalami penurunan dari tahun 2018 sebesar 2,42 ton/ha/musim tanam dan produktivitas jagung mengalami penurunan dari tahun 2018 sebesar 2,30 ton/ha/musim tanam. Persepsi petani tentang Program Upsus Pajale sangat baik, karena penyuluh pertanian lapangan maupun ketua kelompok tani cukup sering memberi informasi tentang Program Upsus Pajale. Petani cukup tahu mengenai tujuan, ruang lingkup, dan sistem pendanaan pada Program Upsus Pajale. Faktor-faktor yang berhubungan dengan persepsi petani dalam Program Upsus Pajale adalah pengalaman berusahatani, motivasi, dan tingkat pengetahuan, sedangkan faktor-faktor yang tidak berhubungan dengan persepsi petani dalam Program Upsus Pajale adalah pendidikan formal, pendidikan nonformal, dan usia petani.

\section{DAFTAR PUSTAKA}

Badan Pusat Statistik Kabupaten Lampung Selatan. (2017). Lampung Selatan Dalam Angka Tahun 2017. Badan Pusat Statistik. Lampung Selatan.

Cindoswari, A.R. dan Abidin, S. (2019). Agenda Setting dan Kredibilitas Harian Tribun Batam dalam Membangun Persepsi Masyarakat di Kota Batam : (Studi Pemberitaan Implementasi Kawasan Ekonomi Khusus). Suluh Pembangunan: Journal of Extension and Development. 1 (1): 22-31.

Dewan Ketahanan Pangan. (2012). Undang-undang No. 18 Tahun 2012 tentang Ketahanan Pangan. Jakarta.

Dewinta RA, Nurmayasari I, dan Sadar S. (2018). Persepsi anggota KPPH terhadap pengelolaan Tahura Di Kelurahan Sumber Agung Kecamatan Kemiling Kota Bandar Lampung. JIIA. Volume 6 No. 3, Agustus 2018. $<$ http://jurnal.fp.unila.ac.id/index.php/ JIIA/article/vie w/3032/2421> (12 Desember 2019).

Haryani EB, Mardikanto T, Ihsaniyati $\mathrm{H}$. (2014). Perespsi Petani Terhadap Program Geranakan Peningkatan Produksi Pangan Berbasis Korporasi (GP3K) di Desa Jati Kecamatan Jaten Kabupaten Karanganyar. Hal 1-11. $<$ https://agribisnis.fp.uns.ac.id/wpcontent/uploads/2014/04/Jurnal-EkoBudi-Hariyani> (12 Desember 2019).

Hasanuddin, T., Viantimala, B., dan Fitriyani, A. (2019). Kinerja Penyuluh Pertanian Lapangan, Kepuasan Petani, dan Produktivitas Usahatani Jagung di Kecamatan Natar, Kabupaten Lampung Selatan. Suluh Pembangunan : Journal of Extension and Development. 1(2): 134-141.

Nurmayasari, I., Viantimala, B., Gultom, D.T., Yanfika, H. dan Mutolib, A. (2020). Partisipasi dan Kepuasan Petani Terhadap Kinerja Penyuluh Pertanian di Kecamatan Palas Kabupaten Lampung Selatan. MIMBAR AGRIBISNIS: Jurnal 
Pemikiran Masyarakat Ilmiah Berwawasan Agribisnis. 6(1): 448459.

Rangga, K.K., Mutolib, A., Yanfika, H., Listiana, I., dan Nurmayasari, I. (2020). Tingkat Efektivitas Penyuluhan Pertanian di Kecamatan Jati Agung Kabupaten Lampung Selatan Jurnal Agribisnis Terpadu. 13 (1): 1-16.

Robiyan R, Hasanuddin T, dan Yanfika H. (2014). Persepsi petani terhadap program SL-PHT dalam meningkatkan produktivitas dan pendapatan usahatani kakao (studi kasus petani kakao di Desa Sukoharjo 1 Kecamatan Sukoharjo Kabupaten Pringsewu). JIIA. Volume 2 No. 3, Juni 2014. <http://jurnal.fp. unila.ac.id/index.php/JIIA/article/view /814/744> (12 Desember 2019).

Siegel S. (1997). Statistik Non Parametrik Untuk Ilmu-Ilmu Sosial. Gramedia. Jakarta.

Sugiarto D, Siagian LT, Sunaryanto, dan Oetomo DS. (2003). Teknik Sampling. PT Gramedia Pustaka Utama. Jakarta.

Sukmayanto, M., Alviana, E.D., Muholib, A. (2019). Persepsi Petani Padi
Terhadap Program Billing System Di Kecamatan Metro Barat Kota Metro. MIMBAR AGRIBISNIS: Jurnal Pemikiran Masyarakat Ilmiah Berwawasan Agribisnis. Januari 2019. 5(1): 114-123.

Viantimala, B., Yanfika, H., Mutolib, A., Listiana, L. dan Effendi, I. (2020). Kinerja Penyuluh dan Partisipasi Petani Dalam Kegiatan Penyuluhan Pertanian Di Kecamatan Kotagajah Kabupaten Lampung Tengah. Journal of Food System and Agribusiness. 4 (1): 9-16.

Wahyuni, S. (2019). Hubungan Karakteristik Inovasi dan Pola Komunikasi Terhadap Keberlanjutan Penerapan Teknologi Padi Salibu di Kabupaten Tanah Datar. Suluh Pembangunan : Journal of Extension and Development. 1 (2): 72-80.

Yanfika, H., Rangga, K.K., Viantimala, B., Listiana, I., Mutolib, A. and Rahmat, A. (2019). Evaluation of the Success of Programs and Strategy for Sustainable Coastal Community Development in Tanggamus Regency. IOP Conf. Series: Journal of Physics: Conf. Series, 1467 (2020) 012026: 19. 